\title{
MANGROVE BARK: A RENEWABLE RESIN SOURCE FOR WOOD ADHESIVES.
}

\author{
Roland E. VETTER ${ }^{1}$, Ana Paula Ribeiro BARBOSA ${ }^{1}$
}

\begin{abstract}
From four solutions tested to extract tannins from mangrove bark for wood adhesives, hot water is recommended. Hot water extracted $21.4 \%$ of formaldehyde-hydrochloric acid reactive polyphenols on oven-dry bark basis.
\end{abstract}

Key words: wood adhesives, wood extractives, tannin, mangrove.

Casca de Mangue: Recurso Renovável de Resina para Adesivos para Madeira

RESUMO - De quatro solventes testados para extrair taninos de casca de mangue para adesivos para madeira, água quente é a mais recomendada. Água quente extraiu $21.4 \%$ de polifenois da casca seca reativos em formaldeido-ácido clorídrico.

Palavras chaves: adesivos para madeira, extrativos de madeira, tanino, mangue.

\section{INTRODUCTION}

Today not only the oil crisis but also ecological movements in the 1990's urge research to substitute petroleum products by renewable natural resources.

Tannin based resins for wood adhesive preparation were studied since the 1950's (DALTON, 1950). Research on use of tannins for particle board adhesives in Brazil were done by PASTORE (1978) and BARBOSA (1990) with material from the bark of wattle (Acacia mearnsii de Wild.). In the Amazon region the bark of mangrove (Rhizophora mangle L.) might be a resource for tannin adhesives. Getting started with research of mangrove bark extracts in adhesives it is worth to know more about the amount of polyphenols in mangrove bark. In this study different solutions were used to make extracts from mangrove bark.

\section{MATERIAL}

The material was milled from the bark of the species Rhizophora mangle, which grows in the eastern part of the Amazon region. The water content of the bark used for the extractions was $24.9 \%$. The extractions were made with different solutions:

- hot water

- ethanol absolute

$-0.5 \%$ aqueous $\mathrm{NaOH}$ (weight/volume)

- $2 \%$ aqueous $\mathrm{Na}_{2} \mathrm{CO}_{3}$ (weight/volume, oven-dry bark basis)

\section{METHOD}

The bark samples for extraction were not dried to prevent possible condensation of phenolic components before extraction. Humidity was determined with separate bark samples in an oven at $105^{\circ} \mathrm{C}$ for 6 hours. Samples of 2 grams (oven-dry bark basis) were extracted with $100 \mathrm{ml}$ solution for one hour at $90^{\circ} \mathrm{C}$ and decanted through a paper filter. Extraction was repeated with the same sample and another 100 $\mathrm{ml}$ solution, again filtered and washed.

1 Instituto Nacional de Pesquisas da Amazônia - INPA, Coordenação de Pesquisas em Produtos Florestais, Caixa Postal 478, 69011-970 - Manaus, Amazonas, Brasil. 
After cooling down, the filtrate and the washings were made up to a $500 \mathrm{ml}$ volume. Each sample extract was analyzed for formaldehyde-hydrochloric acid reactive polyphenols (Stiasny-method; DOAT, 1978):

1. $100 \mathrm{ml}$ of the $500 \mathrm{ml}$ solution were pipetted into an Erlenmeyer flask, 10 $\mathrm{ml}$ of $40 \%$ formaldehyde solution (volume/ volume) and $5 \mathrm{ml}$ concentrated hydrochloric acid were added. After refluxing for 30 minutes the reaction mixture was cooled down and filtered through a filter of medium porosity. The precipitate was washed with $100 \mathrm{ml}$ distilled water, and dried for 2 hours and weighed.

2. Another $100 \mathrm{ml}$ of the extract's solution were dried in an oven at $105^{\circ} \mathrm{C}$ and weighed.

The approximate molecular weight of commercially available Acacia mearnsii tannin for adhesives and the mangrove bark extracts were determined by high pressure liquid chromatography (HPLC) with a stainless steel column, $50 \mathrm{~cm} \times 4.6 \mathrm{~m} \mathrm{ID}$, packed with Licrospher Si 100-10, tetrahydrofuran (THF) as solvent and standards of polystyrene (MW 3000, MW 600). Flow rate was $60 \mathrm{ml}$ per hour and detected by UV $(270 \mathrm{~nm})$.

\section{RESULTS}

The weight of the oven-dry extracts - calculated on oven-dry bark basis - represents the amount of solids which are soluble in the specific solutions, polyphenolic as well as non-polyphenolic components (Tab.1). The resulting content of formaldehyde-hydrochloric acid reactive polyphenols ("Stiasny-phenols") was calculated in percent oven-dry bark and in percent soluble solids (Tab. 1).

The polyphenol amount varies just in a small range using different solutions (between $21.4 \%$ and $26.8 \%$ ). The amount of total extractives (soluble solids) varies from $24.2 \%$ to $57.1 \%$, but the content of nonpolyphenolic components was higher with more soluble solids extracted (Fig. 1). The commercially available "tannin powder" from TANAC SA., Montenegro-RS, Brazil is extracted from plantation grown Acacia mearnsii. This product was also analyzed for formaldehyde-hydrochloric acid reactive polyphenols (Stiasnymethod). The content of "Stiasnyphenols" was $87.7 \%$ (oven-dry basis), which lies in the same range as the hot water extract of mangrove bark (88.7\%; Tab. 1).

The elution volume of the tannin samples, both of Acacia mearnsii and Rhizophora mangle, was $3.5 \mathrm{ml}$ and for the MW600- and MW3000-standards, 3.6 and $3.2 \mathrm{ml}$, respectively, which means that the molecular weight of the samples ranges between 600 and 3000.

Table 1. Percentage of extractives (oven-dry bark basis).

\begin{tabular}{lccc}
\hline \multicolumn{1}{c}{ Solution } & $\begin{array}{c}\text { Soluble solids } \\
\text { Solids }\end{array}$ & $\begin{array}{c}\text { Polyphenols } \\
\text { / o.d. bark }\end{array}$ & $\begin{array}{c}\text { Polyphenols } \\
\text { / o.d. Soluble Solids }\end{array}$ \\
\hline Hot Water & 24.2 & 21.4 & 88.7 \\
Ethanol & 36.6 & 22.8 & 62.5 \\
$0,5 \% \mathrm{NaOH}^{2}$ & 57.1 & 23.2 & 44.8 \\
$2 \% \mathrm{Na}_{2} \mathrm{CO}_{3}$ & 41.3 & 26.8 & 64.9 \\
\hline
\end{tabular}




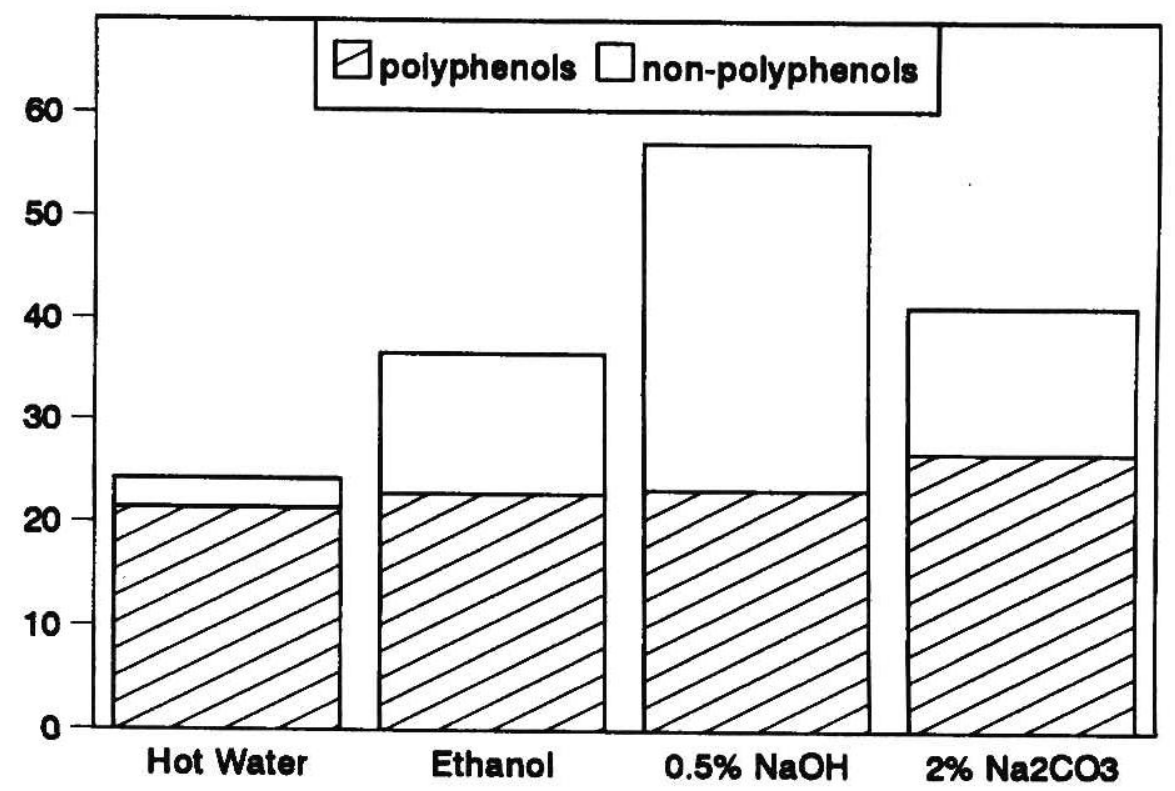

Figure 1. Percentage of extractives (oven-dry bark basis)

\section{DISCUSSION}

Though the amount of "Stiasnyphenols" extracted from mangrove bark with the sodium carbonate solution is $25 \%$ above that of the hot water extract, it must be considered that the properties of the tannin adhesive depend basically on the reaction of the polyphenols with formaldehyde.The amount of the non-phenolic components in the sodium carbonate solution extract is more than three times higher than that in the hot water extract, which, in turn, affects the polymerization of the adhesives resulting in an inferior quality of the end product. Therefore it is recommended to use hot water to extract polyphenolic components from mangrove bark, even if the overall amount is lower than that achieved with the sodium carbonate solution.

The provenance of a natural product should always be taken into account to recommend or not its utilization. The utilization of mangrove bark must not be recommended if it leads to a possible devastation of natural mangrove forests which represent an indispensable protection for the Northern Brazilian coast line against the forces of the ocean. Products from forests under sustainable management and from plantations are considered as renewable resources and, therefore, to be recommended.

\section{Literature cited}

BARBOSA, A. P. 1990. Modificação química de taninos de acácia negra (Acacia mearnsii) para aplicação como adesivos. M.Sc.Thesis, UFRJ, IMA, Rio de Janeiro. viii +196 p. 
DALTON, L. K. 1950. Tannin-formaldehyde resins as hot-press plywood adhesives. Tectona xliii: 137-150.

DOAT, J. 1978. Tannin in tropical woods. Bois. For: Trop. 182: 34-37.

PASTORE Jr., F. 1978. Tannin adhesives. M.Sc.Thesis. The City University, National College of Rubber Technology, London. 118 p. 